The University of San Francisco

USF Scholarship: a digital repository @ Gleeson Library |

Geschke Center

1986

\title{
Repair-Deficient Xeroderma Pigmentosum Cells Made UV Light Resistant by Fusion with X-Ray- Inactivated Chinese Hamster Cells
}

Deneb Karentz

University of San Francisco, karentzd@usfca.edu

James E. Cleaver

Follow this and additional works at: http://repository.usfca.edu/biol_fac

Part of the Biology Commons

\section{Recommended Citation}

D Karentz and J E Cleaver. Repair-deficient xeroderma pigmentosum cells made UV light resistant by fusion with X-ray-inactivated Chinese hamster cells. Mol Cell Biol. 1986 Oct; 6(10): 3428-3432.

This Article is brought to you for free and open access by the Biology at USF Scholarship: a digital repository @ Gleeson Library | Geschke Center. It has been accepted for inclusion in Biology Faculty Publications by an authorized administrator of USF Scholarship: a digital repository@ Gleeson Library | Geschke Center. For more information, please contact repository@usfca.edu. 


\title{
Repair-Deficient Xeroderma Pigmentosum Cells Made UV Light Resistant by Fusion with X-Ray-Inactivated Chinese Hamster Cells
}

\author{
DENEB KARENTZ* AND JAMES E. CLEAVER \\ Laboratory of Radiobiology and Environmental Health, University of California, San Francisco, California 94143
}

Received 27 January 1986/Accepted 24 June 1986

\begin{abstract}
Xeroderma pigmentosum (XP) is an autosomal recessive human disease, characterized by an extreme sensitivity to sunlight, caused by the inability of cells to repair UV light-induced damage to DNA. Cell fusion was used to transfer fragments of Chinese hamster ovary (CHO) chromosomes into XP cells. The hybrid cells exhibited UV resistance and DNA repair characteristics comparable to those expressed by CHO cells, and their DNA had greater homology with CHO DNA than did the DNA from XP cells. Control experiments consisted of fusion of irradiated and unirradiated XP cells and repeated exposure of unfused XP cells to UV doses used for hybrid selection. These treatments did not result in an increase in UV resistance, repair capability, or homology with CHO DNA. The hybrid cell lines do not, therefore, appear to be XP revertants. The establishment of these stable hybrid cell lines is an initial step toward identifying and cloning CHO DNA repair genes that complement the XP defect in human cells. The method should also be applicable to cloning genes for other diseases, such as ataxia-telangiectasia and Fanconi's anemia.
\end{abstract}

Xeroderma pigmentosum (XP) is an inherited human disease caused by a malfunction in the dimer excision step of DNA repair. The disease is manifested as an extreme sensitivity to UV light resulting in the development of skin cancers and, in some cases, neurological disorders. At least nine complementation groups have been identified, indicating that the disease comprises a variety of mutations at several genetic loci $(2,5)$. The genetic basis of the physiological defect of XP has not yet been characterized. Neither genes nor gene products have been identified, and it is not known whether the deficiency is due to mutations in structural or regulatory aspects of DNA repair.

Introduction of isolated DNA into XP cells by standard DNA transfection methods has thus far been unsuccessful in introducing genes that code for UV resistance, presenting a major obstacle to the cloning of genetic information that can complement the deficiency of XP $(12,18)$. In contrast, the introduction of human DNA into repair-deficient hamster cells has resulted in the identification of DNA repair loci not represented in the XP complementation groups $(4,16,21$, 22). We used a method of fusing $X$-irradiated Chinese hamster ovary $(\mathrm{CHO})$ cells with XP cells so that fragments of CHO chromosomes, which appear to support DNA repair, were transferred into the human cells. This report presents the initial work of establishing stable UV-resistant, repaircompetent hybrid cell lines, which will then be used to clone hamster DNA sequences that correct the repair defect of XP cells.

\section{MATERIALS AND METHODS}

Cell lines. Normal human fibroblasts (1508), simian virus 40-transformed normal human fibroblasts (A13-6F and GM637), simian virus 40-transformed XP group A fibroblasts (XP12R0), and Chinese hamster ovary (CHO) cells (AA8) were grown in Eagle minimal essential medium with $10 \%$ fetal calf serum.

Cell fusion. The cell fusion procedure was similar to that described by Cirullo et al. (1) and was adopted because it

\footnotetext{
* Corresponding author.
}

predisposes hybrids to lose hamster chromosomes rather than human chromosomes. $\mathrm{CHO}$ cells were exposed to a lethal dose of $X$ rays $(50 \mathrm{~Gy}, 10 \mathrm{~Gy} / \mathrm{min})$, mixed with approximately equal numbers of unirradiated simian virus 40-transformed XP fibroblasts, and dispersed into $100-\mathrm{mm}$ dishes. After $5 \mathrm{~h}$ at $37^{\circ} \mathrm{C}$, cell fusion was mediated by exposure for $30 \mathrm{~s}$ to $40 \%$ polyethylene glycol 1000 and $10 \%$ dimethyl sulfoxide in minimal essential medium, followed by three rinses with $10 \%$ dimethyl sulfoxide in minimal essential medium. Complete culture medium was added after the final rinse, and cells were incubated overnight. To select for hybrids that contained functional $\mathrm{CHO}$ DNA repair genes and to eliminate unfused XP cells, we irradiated cells with 13 $\mathrm{J}$ of UV light per $\mathrm{m}^{2}\left(254 \mathrm{~nm}, 1.3 \mathrm{~J} / \mathrm{m}^{2}\right.$ per s) once a day for 3 consecutive days. At this dosage, XP12R0 cell survival is $5 \times 10^{-3}$, as determined by colony formation. Cultures were incubated for 2 to 3 weeks until colonies developed, and colonies on each plate were pooled to establish primary hybrid cell lines.

Secondary and tertiary hybrids were developed by fusing $\mathrm{X}$-irradiated primary and secondary hybrids to the original XP cells (Fig. 1). Repeated irradiation and refusion of hybrids to XP cells sequentially reduced the hamster contribution within the hybrid genome to a small amount containing the sequences required for DNA repair. UV-resistant fusion products from the secondary and tertiary fusions were isolated as single colonies to establish genetically homogeneous cell lines. Before each transfer into fresh medium, exposure of hybrid cells to $2.6 \mathrm{~J}$ of $\mathrm{UV}$ light per $\mathrm{m}^{2}(254 \mathrm{~nm}$, $1.3 \mathrm{~J} / \mathrm{m}^{2}$ per s) was used as selection pressure for maintaining UV resistance (DNA repair capability).

Two sets of controls were designed: $X$-irradiated XP cells fused to unirradiated XP cells and screened for UV resistance as described above (these cell lines were designated $\mathrm{X} / \mathrm{X})$ and unfused XP cells subjected to the same doses of UV light as the hybrid cell lines each time they were transferred.

Measurement of cell survival after irradiation. Cell survival was determined both by the acute toxicity of UV light for cells grown in multiwell plates and by colony formation. Cells in wells were exposed to $2.6,5.2$, or $10.4 \mathrm{~J}$ of UV light 


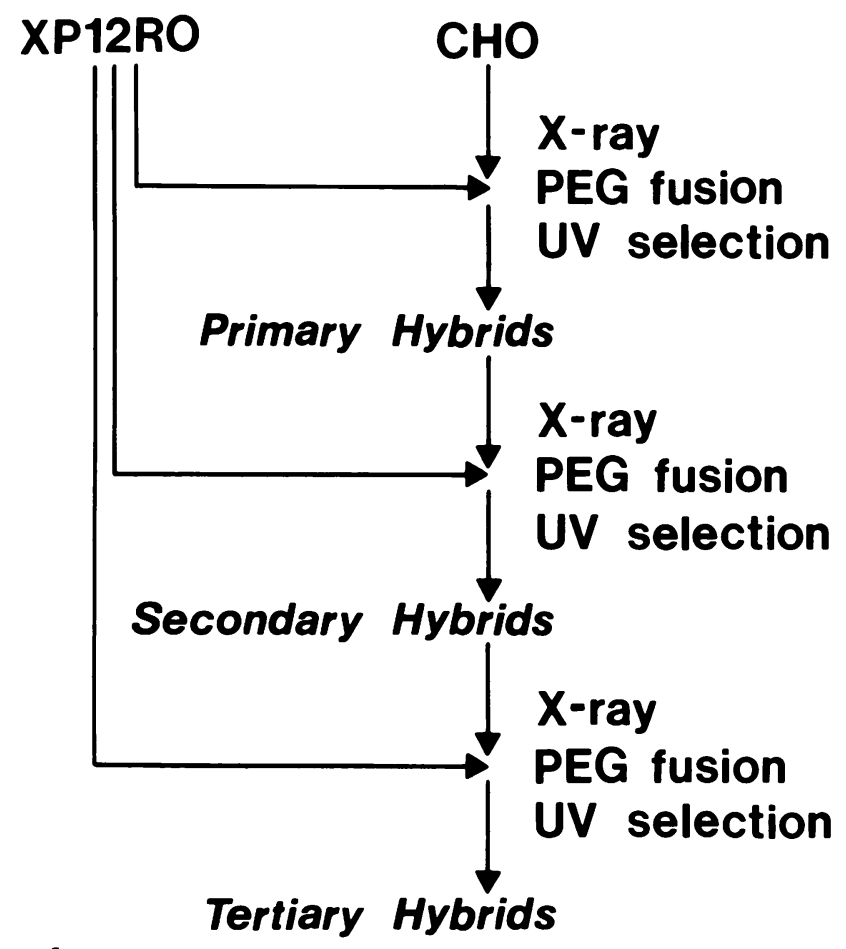

FIG. 1. Outline of procedure used for the establishment of primary, secondary, and tertiary hybrid cell lines. PEG, Polyethylene glycol.

per $\mathrm{m}^{2}$ and grown for 5 days. To determine survival relative to that of unirradiated cells, cultures were incubated for $2 \mathrm{~h}$ with $\left[{ }^{3} \mathrm{H}\right]$ thymidine $\left(\left[{ }^{3} \mathrm{H}\right] \mathrm{dThd}\right)(5 \mu \mathrm{Ci} / \mathrm{ml}, 80 \mathrm{Ci} / \mathrm{mmol})$, DNA was extracted in $4 \%$ perchloric acid at $37^{\circ} \mathrm{C}$, and the radioactivity in each culture was determined. For colony formation, cells were diluted and plated after irradiation and allowed to grow into colonies for 21 days. After fixation and staining, colonies of more than 50 cells were scored.

Measurement of repair replication. The repair replication capability of $\mathrm{CHO}, \mathrm{XP}$, normal human cells, and hybrid cell lines was assessed by means of alkaline cesium chloridecesium sulfate isopycnic gradients (3). Cells were incubated for $24 \mathrm{~h}$ in $\left[{ }^{14} \mathrm{C}\right] \mathrm{dThd}(0.005 \mu \mathrm{Ci} / \mathrm{ml}, 50 \mu \mathrm{Ci} / \mathrm{mmol})$, incubated for $2 \mathrm{~h}$ in $10^{-5} \mathrm{M}$ bromodeoxyuridine (BrdUrd) $-2 \times 10^{-6} \mathrm{M}$ fluorodeoxyuridine to increase density of newly synthesized DNA, exposed to $13 \mathrm{~J} \mathrm{UV} \mathrm{light} \mathrm{per} \mathrm{m}^{2}\left(254 \mathrm{~nm}, 1.3 \mathrm{~J} / \mathrm{m}^{2}\right.$ per s), and incubated for $4 \mathrm{~h}$ with $10^{-5} \mathrm{M}$ BrdUrd-2 $\times 10^{-6} \mathrm{M}$ fluorodeoxyuridine $-2 \times 10^{-3} \mathrm{M}$ hydroxyurea- $\left[{ }^{3} \mathrm{H}\right] \mathrm{dThd}(20$ $\mu \mathrm{Ci} / \mathrm{ml}, 80 \mathrm{Ci} / \mathrm{mmol})$. During the last incubation, repair of thymine dimers formed by UV exposure resulted in the incorporation of ${ }^{3} \mathrm{H}$ label within repair patches. After incubation, the nuclei were isolated and lysed, and DNA was centrifuged in cesium chloride-cesium sulfate isopycnic gradients $(\mathrm{pH} 12.0)$ at $42,000 \mathrm{rpm}$ for $36 \mathrm{~h}$. Fractions were collected, and the radioactivity of each fraction was determined. Fractions containing the DNA represented by the ${ }^{14} \mathrm{C}$-labeled normal density peak were pooled, recentrifuged on the same gradients, and fractionated, and radioactivity profiles were established. Three to four fractions containing the major portion of ${ }^{14} \mathrm{C}$-labeled DNA were pooled, and the ratio of the amount of ${ }^{3} \mathrm{H}$ label to the total DNA concentration (measured spectrophotometrically at $A_{260}$ ) was used as a relative indication of DNA repair capability.

DNA dot blot hybridization. DNA from XP, $\mathrm{CHO}$, and hybrid cells was purified on equilibrium cesium chloride gradients after overnight treatment with proteinase $K$ (14). Denatured DNA $(10 \mu \mathrm{g})$ from each cell line was filtered onto a nitrocellulose filter and hybridized with a ${ }^{3} \mathrm{H}$-labeled probe of total genomic CHO DNA $(10,14)$. After hybridization at $65^{\circ} \mathrm{C}$ (hybridization solution: $10 \%$ dextran sulfate, $5 \times \mathrm{SSC}$ $[1 \times \mathrm{SSC}$ is $0.15 \mathrm{M}$ sodium chloride plus $0.015 \mathrm{M}$ sodium citrate], $0.5 \times$ Denhardt solution, $250 \mu \mathrm{g}$ of denatured salmon sperm DNA per ml, $2 \mathrm{mM}$ phosphate buffer [pH 6.8], and $1 \%$ sodium dodecyl sulfate), filters were rinsed twice $(30 \mathrm{~min}$ each time) with each of the following: $2 \times$ SSC plus $0.5 \%$ sodium dodecyl sulfate at room temperature; $2 \times$ SSC plus $0.1 \%$ sodium dodecyl sulfate at room temperature; $0.1 \times \mathrm{SSC}$ plus $0.2 \%$ sodium dodecyl sulfate at $50^{\circ} \mathrm{C}$; and $0.1 \times \mathrm{SSC}$ at room temperature. Individual sample dots were cut apart, and the amount of radioactivity was determined by liquid scintillation spectrometry. The extent of hybridization was expressed as a percentage of the counts obtained from blots in which CHO DNA was hybridized to itself.

The dot blot analysis was also done with ${ }^{32} \mathrm{P}$-labeled total genomic CHO DNA as the probe. Hybridized filters were exposed to Kodak XAR-2 X-ray film at $-70^{\circ} \mathrm{C}$ with intensifying screens. The autoradiographs were analyzed with a video-densitometer (model 620; Bio-Rad Laboratories) to determine the relative degree of hybridization between different cell lines. The individual sample dots were cut apart, and the radioactivity of each was measured by liquid scintillation spectrometry.

Southern blot. Samples $(10 \mu \mathrm{g})$ of EcoRI-digested DNA from XP, CHO, and two tertiary hybrid cell lines (4A and $\mathrm{BF}$ ) were run on $0.5 \%$ agarose gels ( $25 \mathrm{~V}$, overnight). The DNA was transferred to nitrocellulose filters $(14,19)$. The filters were hybridized with ${ }^{32} \mathrm{P}$-labeled $\mathrm{CHO}$ Alu-equivalent DNA sequences that were cloned from lambda Charon $16 \mathrm{~A}$ bacteriophage (Ch16A-CHOG-49) obtained from W. R. Jelinek. The Alu-equivalent sequences are a family of repeated DNA analogous to the Alu sequences of the human genome (8). Four $\mathrm{CHO}$ Alu-equivalent sequences are included in a 3.3-kilobase pair fragment that was isolated from the phage DNA by EcoRI digestion, gel electrophoresis, and subsequent electroelution of the desired DNA from the gel.

The hybridization conditions for the Southern blot were identical to those described above for the dot blot analysis, except that the third set of rinses in $0.1 \times$ SSC plus $0.2 \%$ sodium dodecyl sulfate was done at $65^{\circ} \mathrm{C}$. The hybridized filters were exposed to Kodak XAR-2 X-ray film at $-70^{\circ} \mathrm{C}$.

\section{RESULTS}

Cell lines. A total of 8 primary, 16 secondary, and 33 tertiary hybrid cell lines were initially recovered. Only two cell lines $(X / X 1$ and $X / X 2)$ were retrieved from the fusion of XP to XP cells, and these showed very little difference from the original XP cells. In the second control group, XP cultures did not survive repeated exposure to the UV doses used on hybrid cell lines.

Cell survival. Both methods used for measuring cell survival indicated that secondary and tertiary hybrid cells had survival characteristics similar to those of $\mathrm{CHO}$ and normal human cells and were considerably more resistant than XP cells (Fig. 2). Several recovered hybrid cell lines that were as UV sensitive as XP presumably resulted from the fusion of XP cells with each other and were discarded. Control cell lines produced by fusion of irradiated to unirradiated XP cells also showed extreme sensitivity to UV, similar to the response of the original repair-deficient cell line. 
Repair capability. In initial isopycnic gradients, ${ }^{3} \mathrm{H}$ peaks at heavy density corresponding to the incorporation of $\left[{ }^{3} \mathrm{H}\right] \mathrm{dTh}$ plus BrdUrd by semiconservative replication were observed in all cell types, and variable amounts of ${ }^{3} \mathrm{H}$ were observed at normal density. To obtain accurate measures of repair replication, we collected and centrifuged normaldensity regions in a second isopycnic gradient. The distribution of ${ }^{3} \mathrm{H}$ radioactivity in the second gradient indicated high levels of repair in the hybrid cells (Fig. 3 and 4). The incorporation of ${ }^{3} \mathrm{H}$ to produce normal-density DNA under these conditions represents incorporation into repair patches formed by excision and replacement of dimers produced by UV exposure. This pattern of repair replication was present in $\mathrm{CHO}$, normal human cells, and hybrid cells but absent in XP cells and the $X / X$ controls, in which no clear peak of ${ }^{3} \mathrm{H}$ could be discerned (Fig. 3 and 4). Ratios of incorporated ${ }^{3} \mathrm{H}$ (labeled nucleotides used in repair patches) to total DNA represent the degree of repair accomplished within each cell line. These values indicate that the hybrid cell lines were

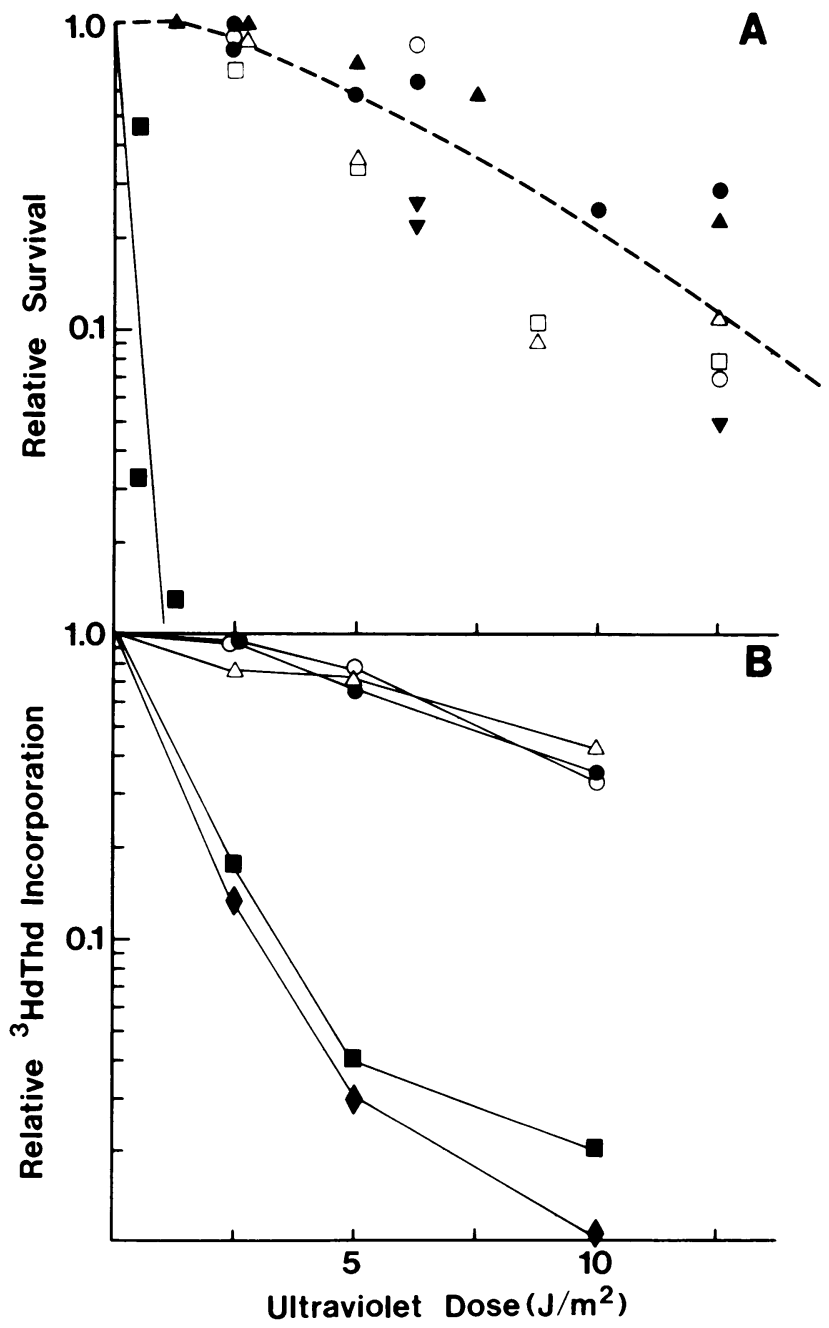

FIG. 2. (A) Relative survival of normal and XP cells after UV exposure, assayed by colony formation. (B) Relative amounts of $\left[{ }^{3} \mathrm{H}\right] \mathrm{dTh}$ incorporation during $2 \mathrm{~h}$ of incubation 5 days after UV exposure. Data are standardized to the values for unirradiated cells of each type, which are considered $100 \%$. Cells used include $\mathrm{CHO}$ cells $(\Theta)$; normal human cells GM637 $(\Delta)$ and A13-6F $(\nabla)$; XP cells $(\square)$; hybrid cells F (O, secondary), 4A ( $\square$, tertiary), and BF ( $\triangle$, tertiary); and XP-XP fused cells $(\diamond)$.

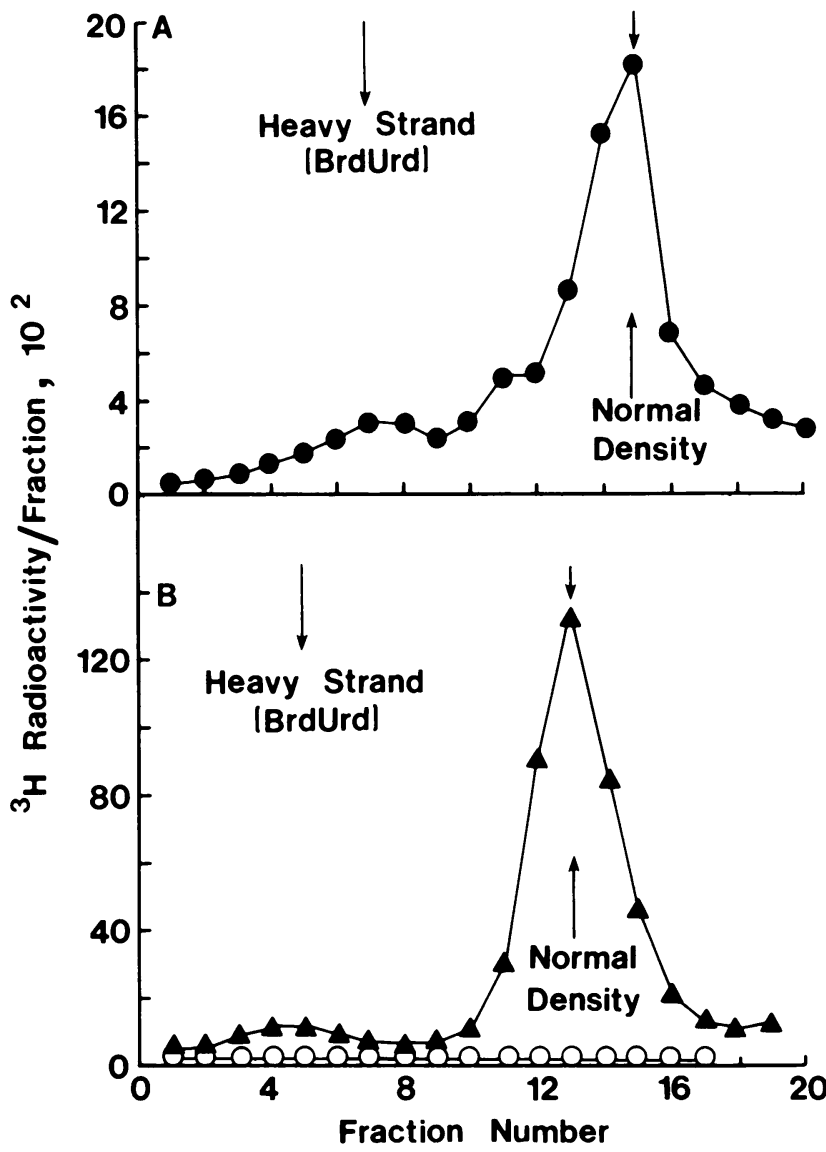

FIG. 3. Alkaline cesium chloride gradients of normal-density DNA isolated from an initial isopycnic gradient of $(\mathrm{A}) \mathrm{CHO}(\bullet)$ and (B) XP $(O)$ and tertiary hybrid BF $(\mathbf{A})$. Arrows at fractions 13 and 15 indicate peak of normal-density ${ }^{14} \mathrm{C}$-labeled DNA in each gradient. Arrows at fractions 5 and 7 indicate peak of heavy $\left[{ }^{3} \mathrm{H}\right] \mathrm{BrdUrd}$ labeled DNA in the initial gradients. All samples contained $95 \mu \mathrm{g}$ of DNA. Cultures were incubated with $\left[{ }^{14} \mathrm{C}\right] \mathrm{dTh}$ to define normaldensity DNA, irradiated with $13 \mathrm{~J}$ of UV light per $\mathrm{m}^{2}$, and then incubated with $\left[{ }^{3} \mathrm{H}\right] \mathrm{dThd}(20 \mu \mathrm{Ci} / \mathrm{ml}, 80 \mathrm{Ci} / \mathrm{mmol}), \operatorname{BrdUrd}\left(10^{-5} \mathrm{M}\right)$, fluorodeoxyuridine $\left(2 \times 10^{-6} \mathrm{M}\right)$, and hydroxyurea $\left(2 \times 10^{-3} \mathrm{M}\right)$.

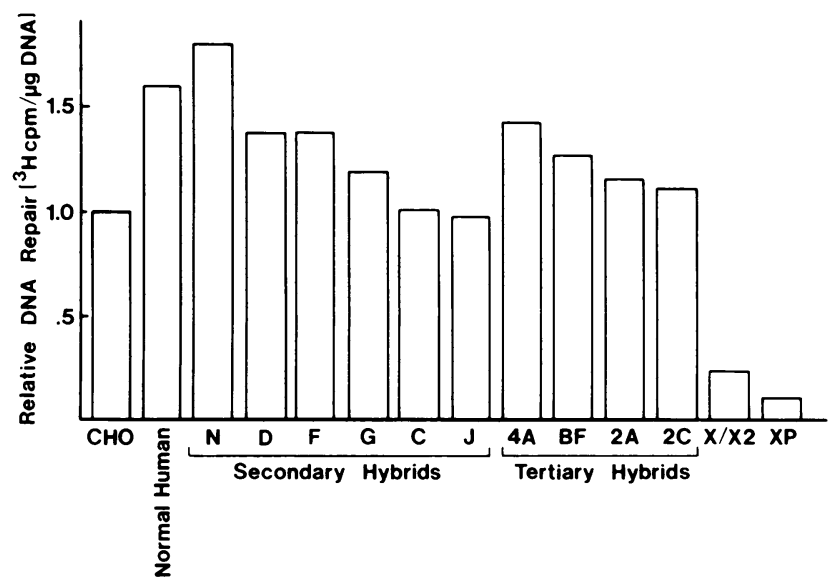

FIG. 4. Ratios of ${ }^{3} \mathrm{H}$ counts per minute in repaired DNA to total concentration of DNA (micrograms per milliliter) from normaldensity peaks of isopycnic gradients similar to those in Fig. 3, for CHO cells, normal human cells, secondary and tertiary hybrids, fused XP-XP cells (X/X2), and XP cells (XP). Data are standardized to values from $\mathrm{CHO}$ cells, which are considered 1.0. 


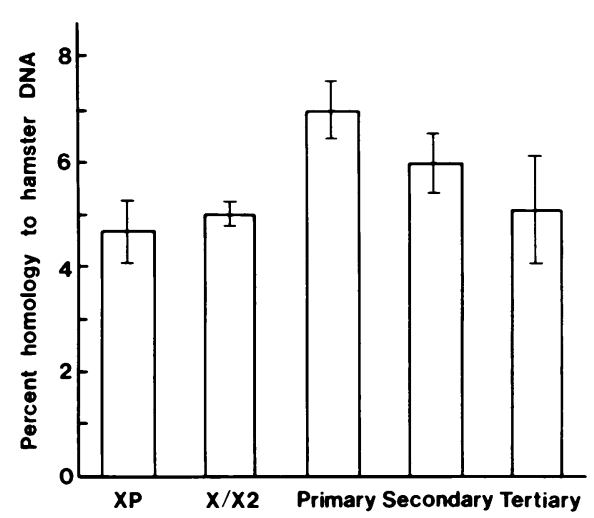

FIG. 5. DNA-DNA dot blot hybridization expressed as percent homology with CHO DNA. XP, fused XP-XP control (X/X2), primary hybrid 5 , secondary hybrid F5, and tertiary hybrid $4 \mathrm{~A}$ are shown. (Bars represent the standard error among three samples.)

capable of repair at a level equal to or slightly greater than that of CHO cells (Fig. 4).

DNA dot blot hybridization. Hybridization with the ${ }^{3} \mathrm{H}$ labeled probe of total genomic CHO DNA indicated that the hybrid cell lines had slightly higher homology with $\mathrm{CHO}$ DNA than did XP or the $\mathrm{X} / \mathrm{X}$ control (Fig. 5). A small decrease in homology was evident from primary to secondary to tertiary clones. These data indicate that the amount of CHO DNA within the hybrid cell lines was reduced with each successive refusion so that tertiary hybrids contained the lowest amount of CHO DNA while still maintaining DNA repair capability.

The autoradiographs, densitometer data, and radioactive measurements of the individual dots from the ${ }^{32} \mathrm{P}$-labeled CHO DNA probe confirmed that the hybrid cells had higher homology with CHO DNA than did XP cells (Fig. 6).

Southern blots. Autoradiographs of the Southern blots obtained by using ${ }^{32} \mathrm{P}$-labeled $\mathrm{CHO}$ Alu-equivalent sequences also showed that there was greater homology between the hybrid genomes and $\mathrm{CHO}$ than between XP and $\mathrm{CHO}$, but no discrete bands were observed. The absence of a banding pattern and the occurrence of a broad band of hybridization along the lane of digested DNA indicate that the hybrid cells had incorporated a variety of CHO DNA sequences that were detected by the $\mathrm{CHO}$ Alu-equivalent probe.

\section{DISCUSSION}

In this study, DNA repair-deficient human cells expressed repair-competent phenotypes after incorporation of fragments of $\mathrm{CHO}$ chromosomes by cell fusion. Hybrid cells showed UV resistance and repair characteristics that were similar to those expressed by $\mathrm{CHO}$ cells and unlike those of the original XP cell line. Furthermore, results of DNA-DNA hybridization clearly demonstrated that DNAs from the hybrid cell lines had a greater homology with CHO DNA than did XP DNA, indicating that the hybrid cell lines had incorporated CHO DNA into their genomes.

The two control experiments, fusion of irradiated XP cells to unirradiated XP cells and repeated exposure of unfused XP cells to the same UV doses used for selecting hybrid lines, did not produce cell lines that had a greater resistance to UV light or that showed any evidence of repair capability or increase in homology with CHO DNA. Because of this and because of the high frequency of UV-resistant cells recovered, we believe that the repair-competent hybrid cell lines are not XP revertants $(15,18)$ but contain DNA sequences transferred from $\mathrm{CHO}$ cells that code for DNA repair.

A simple calculation of expected revertant frequencies also indicates that reversion is unlikely to explain our results. To a first approximation, reversion can occur by point mutation at frequencies similar to those observed, for example, for mutation to diphtheria toxin resistance $(6,15)$. In our study, if reversion had occurred by point mutation as a result of the first dose of UV light used during selection, then this dose of $1.3 \mathrm{~J} / \mathrm{m}^{2}$ would be expected to leave a surviving fraction of $5 \times 10^{-3}$ and to produce a point mutation frequency in XP cells of 20 in $10^{6}$ survivors. Our starting cultures contained approximately $5 \times 10^{6}$ cells, and therefore a dose of $1.3 \mathrm{~J} / \mathrm{m}^{2}$ would produce $5 \times 10^{6} \times 5 \times$ $10^{-3} \times 20 \times 10^{-6}$ point mutations per gene. Assuming $100 \%$ plating efficiency, the number of revertants per dish expected from this calculation would be 0.5 , whereas we obtained about 10 colonies per dish. This calculation actually overstates the revertant frequency, because point mutations would not be expressed for at least 7 days after irradiation (6). Therefore, the three successive doses of $1.3 \mathrm{~J} / \mathrm{m}^{2}$ can be treated as equivalent to a single dose of $3.9 \mathrm{~J} / \mathrm{m}^{2}$, producing a surviving fraction of $1.25 \times 10^{-7}$ and a point mutation frequency of $60 \times 10^{-6}$ per survivor. From a starting population of $5 \times 10^{6}$ cells, the expected number of revertants from this dose would be $5 \times 10^{6} \times 1.25 \times 10^{-7} \times 60 \times$ $10^{-6}$. This estimate of revertant frequencies predicts a yield of about $3.75 \times 10^{-5}$ revertants per dish. In parallel experiments, weekly doses of $3 \mathrm{~J} / \mathrm{m}^{2}$ to XP cells (for a total of 60 $\mathrm{J} / \mathrm{m}^{2}$ ) yielded revertants with a wild-type phenotype only if the cultures had been mutagenized with high concentrations of ethyl methanesulfonate ( 1 to $4 \mathrm{mM}$ ) (Cleaver, unpublished observations).

Additional evidence that cell fusion can result in gene transfer comes from experiments in which hybrids were made between X-irradiated and unirradiated $\mathrm{CHO}$ cells containing selectable gene markers. These experiments indicated that the gene for dihydrofolate reductase could be stably rescued from the $\mathrm{X}$-irradiated partner in approximately $3 \%$ of the hybrid cells (P. Hahn, personal communication).

In previous studies, chromosomal analyses of XP and repair-competent rodent cell hybrids have identified specific mouse (13) and hamster (7) chromosomes that carry the genetic information necessary to complement the repair deficiency in human cells. Human chromosomes $(9,21)$ and specific human DNA sequences $(16,17,22)$ that correct for repair mutations in $\mathrm{CHO}$ cells have also been identified. Although these studies have verified a degree of genetic conservation in the DNA repair pathways of mammals,

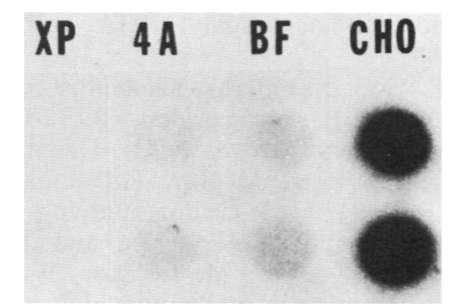

FIG. 6. Autoradiograph of dot blot showing degree of hybridization between genomic DNA of XP, the tertiary hybrids $4 A$ and $B F$, and $\mathrm{CHO}$ with ${ }^{32} \mathrm{P}$-labeled total genomic CHO DNA. 
human chromosomes or DNA sequences that correct repair deficiencies in hamster cells have not yet been found to correct repair deficiencies in human cells (20).

We have not yet identified the precise location of the $\mathrm{CHO}$ DNA in our hybrid cell lines. Giemsa-11 staining and in situ hybridization, two methods of distinguishing rodent DNA from human chromatin, were unsuccessful when applied to the hybrid cells. The in situ hybridizations showed some indication of the presence of CHO DNA, but clear identification was not possible. We believe that the hybrid cells contain a small percentage of CHO DNA that may be widely dispersed and therefore not visible at the microscopic level. The results of the Southern blot analysis support the conclusion that the hybrids contain a variety of CHO DNA sequences. The lack of a more specific probe compounds the difficulty of locating the specific DNA sequence that complements the DNA repair defect of XP.

Our hybrid cell lines represent the first successful attempt to complement a repair defect in human cells with subchromosomal pieces of DNA. We do not know whether the contribution from CHO DNA is in the form of a functional gene or a regulatory component because we do not yet have positive evidence for the location or products of CHO DNA in our hybrids. Since the repair deficiency of XP group $\mathrm{A}$ can be corrected by microinjection of poly $\left(\mathrm{A}^{+}\right)$ mRNA (11), we suspect that a $\mathrm{CHO}$-specific message is present in our hybrids. Current experiments are aimed at identifying and isolating CHO DNA sequences that have been incorporated in the hybrid genomes. We are also attempting to recover $\mathrm{CHO}$-specific gene products through the application of two-dimensional gel analysis of total cell protein.

Stable incorporation of $\mathrm{CHO}$ DNA into human repairdeficient cells is a major step toward identifying and cloning genes involved in the process of DNA repair in human cells and identifying the physiological defect of XP. This method should also be applicable to other complex disorders such as ataxia-telangiectasia and Fanconi's anemia, for which direct cloning by transfection with genomic DNA has not been successful but for which selection systems are available.

\section{ACKNOWLEDGMENTS}

This work was supported by the Office of Health and Environmental Research, U.S. Department of Energy, contract DE-AC0376-SF01012, and by National Institutes of Health National Research Service Award 5 T32 ES07106 from the National Institute of Environmental Health Sciences.

We are grateful to M. McKenney and S. Brekhus for editorial and secretarial assistance.

\section{LITERATURE CITED}

1. Cirullo, R. E., S. Dana, and J. J. Wasmuth. 1983. Efficient procedure for transferring specific human genes into Chinese hamster cell mutants: interspecific transfer of the human genes encoding leucyl- and asparaginyl-tRNA synthetases. Mol. Cell. Biol. 3:892-902.

2. Cleaver, J. E. 1983. Xeroderma pigmentosum, p. 1227-1248. In J. B. Stanbury, J. B. Wyngaarden, D. S. Fredrickson, J. L. Goldstein, and M. S. Brown (ed.), The metabolic basis of inherited disease, 5th ed. McGraw-Hill Book Co., New York.

3. Cleaver, J. E. 1984. Methods for studying excision repair of eukaryotic DNA damaged by physical and chemical mutagens, p. 33-69. In B. J. Kilbey, M. Legator, W. Nichols, and C. Ramel (ed.), Handbook of mutagenicity test procedures.
Elsevier Science Publishers, Amsterdam.

4. Ding, R., K. Ghosh, A. Eastman, and E. Bresnick. 1985. DNAmediated transfer and expression of a human DNA repair gene that demethylates $O^{6}$-methylguanine. Mol. Cell. Biol. 5:32933296.

5. Fischer, E., W. Keijzer, H. W. Thielmann, O. Popanda, E. Bohnert, L. Edler, E. G. Jung, and D. Bootsma. 1985. A ninth complementation group in xeroderma pigmentosum, XP I. Mutat. Res. 145:217-225.

6. Glover, T. W., C.-C. Chang, J. E. Trosko, and S. S.-L. Li. 1979. Ultraviolet light induction of diphtheria toxin-resistant mutants in normal and xeroderma pigmentosum human fibroblasts. Proc. Natl. Acad. Sci. USA 76:3982-3986.

7. Goldstein, S., and C. C. Lin. 1972. Survival and DNA repair of somatic cell hybrids after ultraviolet irradiation. Nature (London) New Biol. 239:142-145.

8. Haynes, S. R., T. P. Toomey, L. Leinwand, and W. R. Jelinek. 1981. The Chinese hamster Alu-equivalent sequence: a conserved, highly repetitious, interspersed deoxyribonucleic acid sequence in mammals has a structure suggestive of a transposable element. Mol. Cell. Biol. 1:573-583.

9. Hori, T., T. Shiomi, and K. Sato. 1983. Human chromosome 13 compensates a DNA repair defect in UV-sensitive mouse cells by mouse-human cell hybridization. Proc. Natl. Acad. Sci. USA 80:5655-5659.

10. Kafatos, F. C., C. W. Jones, and A. Efstratiadis. 1979. Determination of nucleic acid sequence homologies and relative concentrations by a dot hybridization procedure. Nucleic Acids Res. 7:1541-1552.

11. Legerski, R. J., D. B. Brown, C. A. Peterson, and D. L. Robberson. 1984. Transient complementation of xeroderma pigmentosum cells by microinjection of poly $(\mathrm{A})^{+}$RNA. Proc. Natl. Acad. Sci. USA 81:5676-5679.

12. Lehmann, A. R. 1985 . Use of recombinant DNA techniques in cloning DNA repair genes and in the study of mutagenesis in mammalian cells. Mutat. Res. 150:61-67.

13. Lin, P., and F. H. Ruddle. 1981. Murine DNA repair gene located on chromosome 4. Nature (London) 289:191-194.

14. Maniatis, T., E. F. Fritsch, and J. Sambrook. 1982. Molecular cloning: a laboratory manual. Cold Spring Harbor Laboratory, Cold Spring Harbor, N.Y.

15. Royer-Pokora, B., and W. A. Haseltine. 1984. Isolation of UV-resistant revertants from a xeroderma pigmentosum complementation group A cell line. Nature (London) 311:390-394.

16. Rubin, J. S., A. L. Joyner, A. Bernstein, and G. F. Whitmore. 1983. Molecular identification of a human DNA repair gene following DNA-mediated gene transfer. Nature (London) 306:206-208.

17. Rubin, J. S., V. R. Prideaux, H. F. Willard, A. M. Dulhanty, G. F. Whitmore, and A. Bernstein. 1985. Molecular cloning and chromosomal localization of DNA sequences associated with a human DNA repair gene. Mol. Cell. Biol. 5:398-405.

18. Schultz, R. A., D. P. Barbis, and E. C. Friedberg. 1985. Studies on gene transfer and reversion to UV resistance in xeroderma pigmentosum cells. Somatic Cell Genet. 11:617-624.

19. Southern, E. M. 1975 . Detection of specific sequences among DNA fragments separated by gel electrophoresis. J. Mol. Biol. 98:503-517.

20. Thompson, L. H., C. L. Mooney, and K. W. Brookman. 1985. Genetic complementation between UV-sensitive CHO mutants and xeroderma pigmentosum fibroblasts. Mutat. Res. 150: 423-429.

21. Thompson, L. H., C. L. Mooney, K. Burkhart-Schultz, A. V. Carrano, and M. J. Siciliano. 1985. Correction of a nucleotideexcision-repair mutation by human chromosome 19 in hamsterhuman hybrid cells. Somatic Cell Mol. Gen. 11:87-92.

22. Westerveld, A., J. H. J. Hoeijmakers, M. van Duin, J. De Wit, H. Odijk, A Pastink, R. D. Wood, and D. Bootsma. 1984. Molecular cloning of a human DNA repair gene. Nature (London) 310:425-429. 